\title{
Near-surface Palaeocene fluid flow, mineralisation and faulting at Flamborough Head, UK: new field observations and $\mathrm{U}-\mathrm{Pb}$ calcite dating constraints
}

\author{
Nick M. W. Roberts ${ }^{1}$, Jack K. Lee ${ }^{1,2}$, Robert E. Holdsworth ${ }^{2}$, Christopher Jeans ${ }^{3}$, Andrew R. Farrant ${ }^{4}$, and \\ Richard Haslam 4 \\ ${ }^{1}$ Geochronology and Tracers Facility, British Geological Survey, Environmental Science Centre, \\ Nottingham, NG12 5GG, UK \\ ${ }^{2}$ Department of Earth Sciences, Durham University, Science Labs, Durham, UK \\ ${ }^{3}$ Department of Earth Sciences, University of Cambridge, Downing Place, Cambridge, UK \\ ${ }^{4}$ British Geological Survey, Environmental Science Centre, Nottingham, UK
}

Correspondence: Nick M. W. Roberts (nirob@bgs.ac.uk)

Received: 29 April 2020 - Discussion started: 6 May 2020

Revised: 22 July 2020 - Accepted: 9 September 2020 - Published: 28 October 2020

\begin{abstract}
We present new field observations from Selwicks Bay, NE England, an exposure of the Flamborough Head Fault Zone (FHFZ). We combine these with U-Pb geochronology of syn- to post-tectonic calcite mineralisation to provide absolute constraints on the timing of deformation. The extensional frontal fault zone, located within the FHFZ, was active at ca. $63 \mathrm{Ma}$, with protracted fluid activity occurring as late as ca. $55 \mathrm{Ma}$. Other dated tensile fractures overlap this time frame and also cross-cut earlier formed fold structures, providing a lower bracket for the timing of folding and compressional deformation. The frontal fault zone acted as a conduit for voluminous fluid flow, linking deeper sedimentary units to the shallow subsurface, potentially hosting open voids at depth for a significant period of time, and exhibiting a protracted history of fracturing and fluid flow over several million years. Such fault-hosted fluid pathways are important considerations in understanding chalk reservoirs and utilisation of the subsurface for exploration, extraction and storage of raw and waste materials. Most structures at Selwicks Bay may have formed in a deformation history that is simpler than previously interpreted, with a protracted phase of extensional and strike-slip motion along the FHFZ. The timing of this deformation overlaps that of the nearby Cleveland Dyke intrusion and of regional uplift in NW Britain, opening the possibility that extensional deformation and hy-
\end{abstract}

drothermal mineralisation at Selwicks Bay are linked to these regional and far-field processes during the Palaeocene.

\section{Introduction}

Faulting of sedimentary basin fills in the subsurface is an important process in producing structurally constrained aquifers and reservoirs, as well as providing potential conduits and barriers to fluid resource migration and accumulation. Fault- and fracture-hosted infill and mineralisation allow us to assess the character and scale of along-fault fluid migration. Maintenance of open fractures is an increasingly recognised phenomenon in faults formed in the shallowest parts of the crust down to depths of 1-2 km (e.g. Wright et al., 2009; van Gent et al., 2010; von Hagke et al., 2019). Open or partially open fractures can be propped open and preserved in the subsurface when they become infilled by wall rock collapse breccias, waterborne sediments and/or hydrothermal mineralisation (e.g. Walker et al., 2011; Holdsworth et al., 2019, 2020). These so-called fissure systems have the potential to act as significant channelways for the migration and storage of subsurface fluids such as water, hydrocarbons or geothermal fluids. In carbonate aquifers, they can also act as pathways for the development of larger dissolutional conduits and cave systems. 
The absolute timings of fracture opening and fault displacement are critical to understanding how subsurface fluid migration evolves over time and link individual fractures to the record of external tectonic deformation. Most sedimentary basins, whether ancient or currently active, lack direct chronological constraints on their structural history and rely instead on the interpretation of stratigraphical and structural relations from field data or those imaged by geophysical means, e.g. seismic reflection data. Exposed faults can be directly dated if suitable geochronometers are preserved; recent methodological developments have broadened the range of such mineral chronometers. Clay minerals can be dated by $\mathrm{K}-\mathrm{Ar}$, $\mathrm{Ar}-\mathrm{Ar}$ and $\mathrm{Rb}-\mathrm{Sr}$, but they require fault gouge and a meticulous analytical approach to generate robust dates (e.g. Viola et al., 2016). U-Th / He dating of hematite coatings (e.g. Ault et al., 2016), U-Th-Pb dating of hydrothermal monazite (Bergemann et al., 2018), $\mathrm{Rb}-\mathrm{Sr}$ dating of feldspar (Tillberg et al., 2020) and Re-Os dating of hydrothermal sulfides (e.g. Dichiarante et al., 2016) are promising techniques that are also of use for faults and fault-hosted mineralisation of the right composition. In this paper, we utilise $\mathrm{U}-\mathrm{Pb}$ dating of vein-filling calcite. Calcite is an extremely abundant mineral fill in brittle fractures and faults of wideranging host lithologies. It has been shown to be an effective chronometer that can be linked to the timing of hydrothermal mineralisation, fault slip and fold development (Roberts and Walker, 2016; Ring and Gerdes, 2016; Goodfellow et al., 2017; Nuriel et al., 2017, 2019; Beaudoin et al., 2018; Hansman et al., 2018; Holdsworth et al., 2019, 2020; Parrish et al., 2018; Smeraglia et al., 2019; Roberts et al., 2020).

In ancient sedimentary basin systems worldwide, many episodes of uplift and deformation are a consequence of tectonic inversion associated with the far-field effects of orogenesis. In the British Isles, the youngest of these events are Cenozoic and may be related to either the Palaeogene Pyrenean or Neogene Alpine orogeny, both of which have been linked to major geological structures exposed across Southern England (e.g. see Chadwick, 1993; Blundell, 2002; Parrish et al., 2018). However, these may also have led to deformation as far north as Yorkshire and offshore in the southern North Sea (Ziegler, 1989). Here we present data from the Flamborough Head Fault Zone (FHFZ), which forms the southern boundary to the Mesozoic Cleveland Basin, and for which there is no present consensus as to the timing and kinematic history. In this paper, we combine new field observations with $\mathrm{U}-\mathrm{Pb}$ geochronology of calcite veins. Our dates present the first absolute timing constraints on deformation within the FHFZ and are placed into context with new field observations pertinent to understanding the structural setting of associated fluid flow and fracture-filling processes.

\section{Geological setting}

The Mesozoic Cleveland Basin (Fig. 1a) located in East Yorkshire, northern England, has experienced inversion, the timing of which is poorly constrained. It is attributed by most authors to distant effects of the Pyrenean or Alpine orogeny (e.g. Starmer, 1995). The Jurassic-Cretaceous basin fills are bounded to the north and south by complex fault zones. To the south, the FHFZ is an east-west-striking zone of brittle faults, which separates the Cleveland Basin from the Market Weighton Block (Fig. 1a). Inland exposures of the fault zone are poor and largely restricted to small quarries in Cretaceous chalk; however, they can be mapped on the surface and are visible on remotely sensed datasets (Farrant et al., 2016). In contrast, the coastline preserves excellent exposures of the faults and associated deformation. Flamborough Head (Fig. 1b) exposes several fault zones that have a complex structure and potentially a protracted history; these are the Bempton, Selwicks Bay and Dykes End fault zones (Fig. 1b). The chalk at Flamborough Head is amongst the youngest exposed in Yorkshire and comprises the Burnham Chalk Formation (late Coniacian to early Santonian) and the overlying Flamborough Chalk Formation (Santonian) (see Whitham, 1993; Mortimore, 2019).

The FHFZ is an E-W zone of brittle faults exposed at the coast at Flamborough Head, extending inland for 50 to $60 \mathrm{~km}$ (see Fig. 1a and Farrant et al., 2016). The fault zone is linked with the Vale of Pickering Fault Zone (Kirby and Swallow, 1987) and has also been referred to as the Howardian Hills-Flamborough Fault Belt (Starmer, 1995). To the east, the fault zone is truncated offshore by the Dowsing Fault Zone, which forms the western margin of the Sole Pit Basin. The deformation of the Cretaceous chalk rocks around Flamborough Head associated with some of the E-W faults has long been studied due to the excellent and structurally complex exposures preserved here (e.g. Phillips, 1829; Lamplugh, 1895; Kent et al., 1974; Kent, 1980; Kirby and Swallow, 1987; Peacock and Sanderson, 1994; Starmer, 1995, 2008, 2013; Rawson and Wright, 2000; Sagi et al., 2016).

Previous geological constraints on the timing of fault movements within the FHFZ come from the interpretation of seismic reflection data and sedimentological and structural analyses of several key outcrops (Jeans, 1973; Kirby and Swallow, 1987; Starmer, 1995). The offshore seismic interpretation of Kirby and Swallow (1987) indicates the existence of both steep faults that cut underlying Permian and Carboniferous strata at depth and listric faults that detach within the Permian Zechstein strata. Faults on the northern and southern margins of the fault zone form a graben structure. Thickness changes of the Speeton Clay and Hunstanton Formation have been interpreted as evidence that the northern fault zone (comprising the Bempton and Speeton faults; Fig. 1b) began movement in the Early Cretaceous (Jeans, 1973; Kirby and Swallow, 1987). Kirby and Swallow (1987) concluded that an early stage of near-vertical normal fault- 


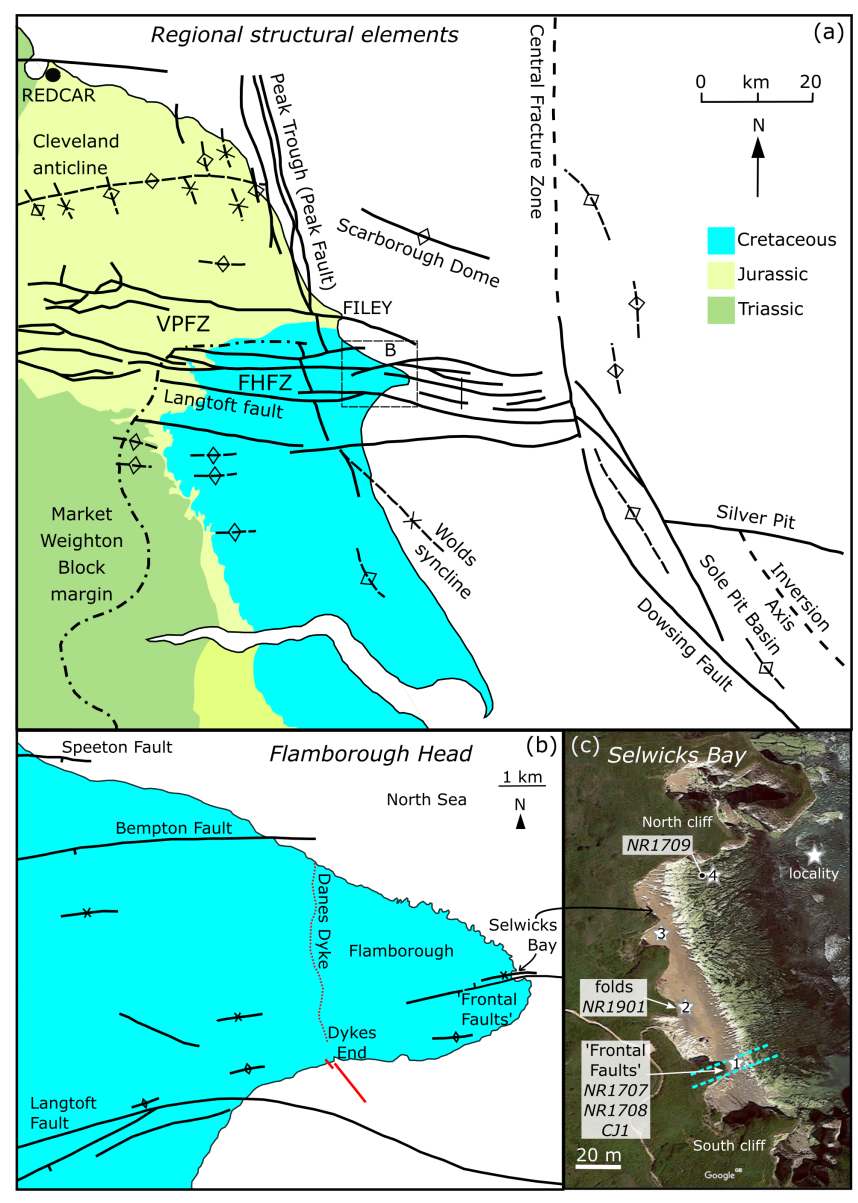

Figure 1. (a) Geological sketch map of the region around Flamborough Head, NE England, showing the regional structural elements. Modified after Powell (2010) and Starmer (1995), reproduced with permission of the Council of the Yorkshire Geological Society. (b) Geological sketch map of Flamborough Head showing main structural features. Modified after Starmer (2013), reproduced with permission of the Council of the Yorkshire Geological Society. (c) Satellite image of Selwicks Bay showing location of samples. Google map data: imagery (C) 2020 CNES/Airbus, Getmapping plc, Infoterra Ltd \& Bluesky, Maxar Technologies, map data (C) 2020.

ing (Early Cretaceous) produced the graben structure, which was then followed by a period of listric normal faulting, with both events occurring prior to the Late Cretaceous. Inversion of the former extensional structures, forming the "shatter zones" at Bempton and Selwicks Bay, is inferred to have occurred at the end of the Cretaceous and has been related to the more regional uplift, folding and inversion of the Cleveland Basin to the north, forming, amongst other structures, the Cleveland Anticline (Fig. 1a, Kirby et al., 1987).

Peacock and Sanderson (1994) conducted a detailed investigation of the orientation and displacements of faults exposed around Flamborough Head, covering some 1340 individual structures. They interpret their data as indicating that sigmal during faulting was subvertical, with extension oc- curring subhorizontally in all directions, and that complex relationships existed between sigma2 and sigma3. Based on oblique-slip kinematics they suggested that a subhorizontal sigma3 developed over time in a dominantly NNW-SSE direction. These authors also briefly describe the existence of contractional structures, namely oblique or reverse displacements on some fault surfaces, with a NNW-SSE contraction direction. Brecciation and veining are pervasive at Selwicks Bay, and Peacock and Sanderson (1994) tentatively suggest that both were related to the contractional event. They do not, however, present clear evidence for whether contraction preceded or followed extension.

Starmer (1995) produced a deformation history of the chalk at Selwicks Bay based on detailed mapping and structural analyses in onshore exposures of chalk; he describes four phases of deformation (D1 to D4). D1 produced folds with NNW-SSE axes and bedding plane-parallel shears, with an ENE-WSW to E-W shortening direction. Subsequent D2 deformation was attributed to extension in an E$\mathrm{W}$ direction and the formation of tensional extensional fractures. D3 started with E-W-directed flexure of the strata and some strike-slip faulting. Once the folds had tightened, thrusts with top-to-the-S to top-to-the-SSE shear sense directions cut through the strata. Dextral strike-slip at the same time suggests a transpressional strain. D4 was interpreted as a complex phase of extension-transtension, first with E$\mathrm{W}$ extension allowing $\mathrm{N}-\mathrm{S}$ structures to activate and followed by a N-S component of extension. Starmer (1995) links these events to "Laramide" (late Maastrichtian to early Palaeocene) compression (D1), "Laramide" extension (D2), Alpine (Oligocene) compression (D3) and post-Alpine extension (D4).

Sagi et al. (2016) studied the exposures at both Selwicks Bay and Dykes End (see Fig. 1b), analysing the fault density and connectivity in particular, as well as the relationship of these to fluid flow. These authors describe numerous occurrences of dilational and contractional jogs occurring along the fault planes, exhibiting textures that include pressure solution styolites and coarse-crystalline calcite vein fill. At Selwicks Bay, Sagi et al. (2016) focused on two large, steeply dipping ENE-WSE normal faults that are a distinctive structural feature (the frontal faults of Starmer, 1995), related to folding and intense metre-scale zones of intense veining and brecciation in the chalk wall rocks. These authors describe the damage zones associated with this set of faults (the Selwicks Bay "Shatter Zone") and show that they are 4 to $5 \mathrm{~m}$ wide in the footwall but less than $1 \mathrm{~m}$ wide in the hanging wall. These brecciated damage zones are where the highest intensity of veining occurs, forming a highly interconnected, braided network of tensile calcite-filled fractures. This study showed that fluid connectivity was much higher in the damage zones of the faults (up to $60 \%$ ) compared the surrounding wall rock (less than $10 \%$ ), i.e. that these faults unequivocally represented highly effective fluid conduits in the geological past. 
Faÿ-Gomard et al. (2018) present a geochemical study of veining at Selwicks Bay and describe a relative chronology of three different phases of calcite veining. They use clumped isotopes of carbonates to determine precipitation temperatures of ca. $60^{\circ} \mathrm{C}$ and, combined with carbon, oxygen and strontium isotope analyses, postulate that the fluids originate from the underlying Triassic Sherwood Sandstone. These authors link the timing of veining to late Mesozoic to Cenozoic basin inversion, suggesting veining may have occurred in a pulsed manner linked to phases of inversion. However, in their figure, they utilise the burial history curve of Emery (2016), correlating the veining with OligoceneMiocene regional uplift.

Mortimore (2019) revisited the stratigraphy of the chalk exposed at Selwicks Bay, providing new stratigraphic and sedimentological $\operatorname{logs}$ for exposures north and south of the frontal faults. Mortimore (2019) also re-evaluated both micro- and macro-scale structures and sedimentological features exposed at Selwicks Bay, questioning whether many of those exposed are a result of synsedimentary slumping and downslope displacement, rather than being purely tectonic processes.

\section{Methodology}

Fieldwork focussed on examples of calcite mineralisation associated with folds, fractures and faults in the well-exposed Selwicks Bay (Fig. 1c). Several samples of calcite mineralisation were collected for $\mathrm{U}-\mathrm{Pb}$ dating purposes, with additional material collected from some fracture fills in order to understand the geological context of fracture-filling processes. Thin sections from these samples were studied optically in order to characterise the mineralogy, structural setting and - where possible - the sequence of fracture filling in each sample.

$\mathrm{U}-\mathrm{Pb}$ geochronology was conducted at the Geochronology and Tracers Facility, British Geological Survey, UK. Samples were analysed using polished epoxy blocks/slabs. The instrumentation used was a New Wave Research 193UC excimer laser ablation system fitted with a TV2 cell, coupled to a $\mathrm{Nu}$ Instruments Attom single-collector inductively coupled plasma mass spectrometer (ICP-MS). The method follows that described in Roberts et al. (2017). Laser parameters were pre-ablation conditions of $150 \mu \mathrm{m}$ static spots fired at $10 \mathrm{~Hz}$ with a fluence of $\sim 8 \mathrm{~J} \mathrm{~cm}^{-2}$ for $2 \mathrm{~s}$ and ablation conditions of a $100 \mu \mathrm{m}$ spot, fired at $10 \mathrm{~Hz}$ with a fluence of $\sim 8 \mathrm{~J} \mathrm{~cm}^{-2}$ for $30 \mathrm{~s}$. A $60 \mathrm{~s}$ background is taken before every set of standard-bracketed analyses, and a $5 \mathrm{~s}$ washout is left between each ablation. Data reduction uses the time-resolved analysis function of the $\mathrm{Nu}$ Instruments AttoLab software and an Excel spreadsheet. Isoplot v4 (Ludwig, 2011) is used for calculation and plotting of ages. Uncertainty propagation follows the recommendations of Horstwood et al. (2016), with final dates including propagation of systematic uncer- tainties. The carbonate material WC-1 (254 Ma; Roberts et al., 2017) was used as the primary reference material, and Duff Brown Tank (64.04 Ma; Hill et al., 2016) and ASH15D (2.965 Ma; Nuriel et al., 2020) were used as validation materials. The pooled result of all Duff Brown analyses yields a lower intercept age of $65.4 \pm 1.2 \mathrm{Ma}$, and the pooled result of ASH15D yields a lower intercept age of $2.88 \pm 0.08 \mathrm{Ma}$.

\section{Outcrop settings of samples}

It is not our intention here to provide a detailed kinematic analysis of faulting in the region. Instead, it is our objective to simply provide the context for our new $\mathrm{U}-\mathrm{Pb}$ dates in terms of the general movement history of the fault zones and the associated hydrothermal mineralisation.

Our sampling comes from three outcrop locations (Fig. 1c); all photographs in the following sections relate to these three localities and a fourth that was not sampled. Locality 1 is the damage zone between the two E-W-striking "frontal faults" (Frontal Fault North and Frontal Fault South), of Starmer (1995), also termed the intensely brecciated zone (IBZ) by Sagi et al. (2016). The combined displacement across these faults has been estimated as $\sim 20 \mathrm{~m}$ based on stratigraphic offsets (Rawson and Wright, 2000; Mortimore, 2019), with downthrow to the north. The two faults separate a $4-5 \mathrm{~m}$ wide zone of highly calcite veined, variably misoriented and brecciated chalk (Figs. 2a-d, 3a-d). The areas of breccia are highly variable in their development - some smaller examples up to $20 \mathrm{~cm}$ wide are fairly constant in thickness and are bounded by well-defined planar fracture surfaces (Fig. 3b), whilst others are more irregular, with diffuse margins, varying between a few centimetres to more than $1.5 \mathrm{~m}$ across. As noted by Sagi et al. (2016), many veins in the brecciated panel between the two bounding faults show geometries consistent with tensile (Mode I) opening during normal faulting (Fig. 3b), with the development of well-defined median lines and, in places, open vuggy cavities suggesting syntaxial mineralisation into large open voids (Woodcock et al., 2014). Three samples comes from this damage zone. CJ-1 is from coarse-grained (up to $10 \mathrm{~cm}$ ) calcite grown in an open vug within the cliff (similar to Fig. 3b). NR1707 and NR1708 are from the calcite cement within the damage zone breccia, located on the foreshore approximately $20 \mathrm{~m}$ from the main cliff. NR1707 is from the main matrix cement, and NR1708 is from a vein of calcite cement that is located within a chalk of pebble (Fig. $2 b-d$ )

Locality 2 is the region of folding in the middle of the bay, approximately $30 \mathrm{~m}$ north of the frontal faults and Locality 1 . The sample NR1901 comes from a tight synformal fold (Figs. 2e, 4c). Here, a metre-scale, close-to-tight, southwardverging antiform-synform pair is developed and is closely associated with at least two top-to-the-S low-to-moderately $\mathrm{N}$-dipping thrust faults (Fig. 4c). The exposed synformal fold hinge reveals bedding-parallel calcite slickenfibres oriented 

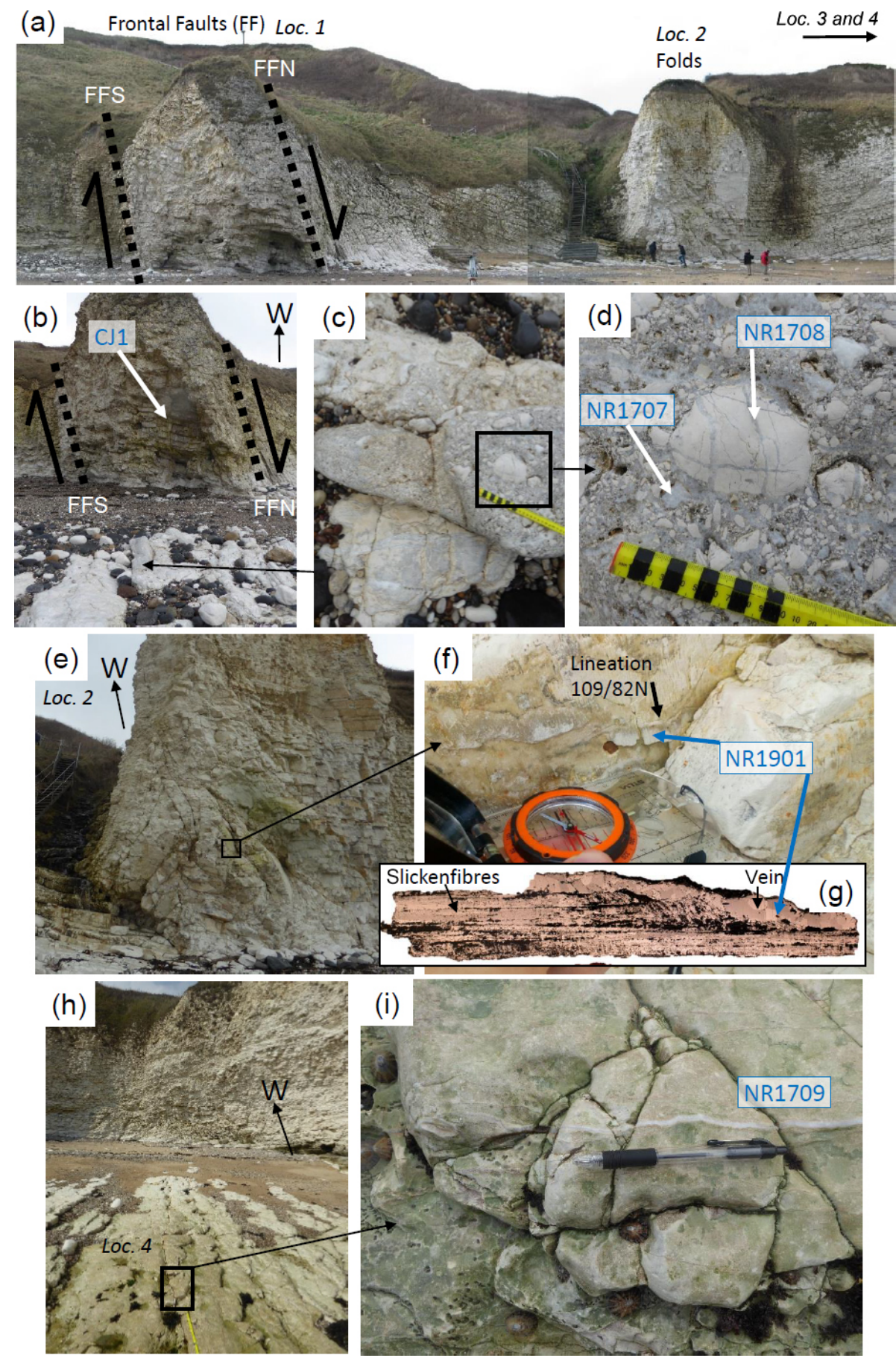

Figure 2. (a) View looking west of both the frontal faults (Locality 1) and region of tight folding (Locality 2). FFS: Frontal Fault South; FFN: Frontal Fault North. (b) Frontal fault zone with location of samples NR1707 and NR1708 on foreshore. (c) Chaotic breccia fissure fill cemented by calcite with location of samples. (d) Close-up of clast with calcite vein (sample NR1708) and breccia cement (NR1707). (e) Locality 2 showing the location of sample NR1901 on the hinge of a fold. (f) Slickenfibres located on the bedding plane in the fold hinge. (g) Reflected light photograph of cross-section view of slickenfibres and cross-cutting sparry vein; sample NR1901. (h) Locality 4 showing the foreshore pavement with subvertical E-W-striking calcite-filled veins. (i) Close-up of Locality 4 and sample NR1709. 


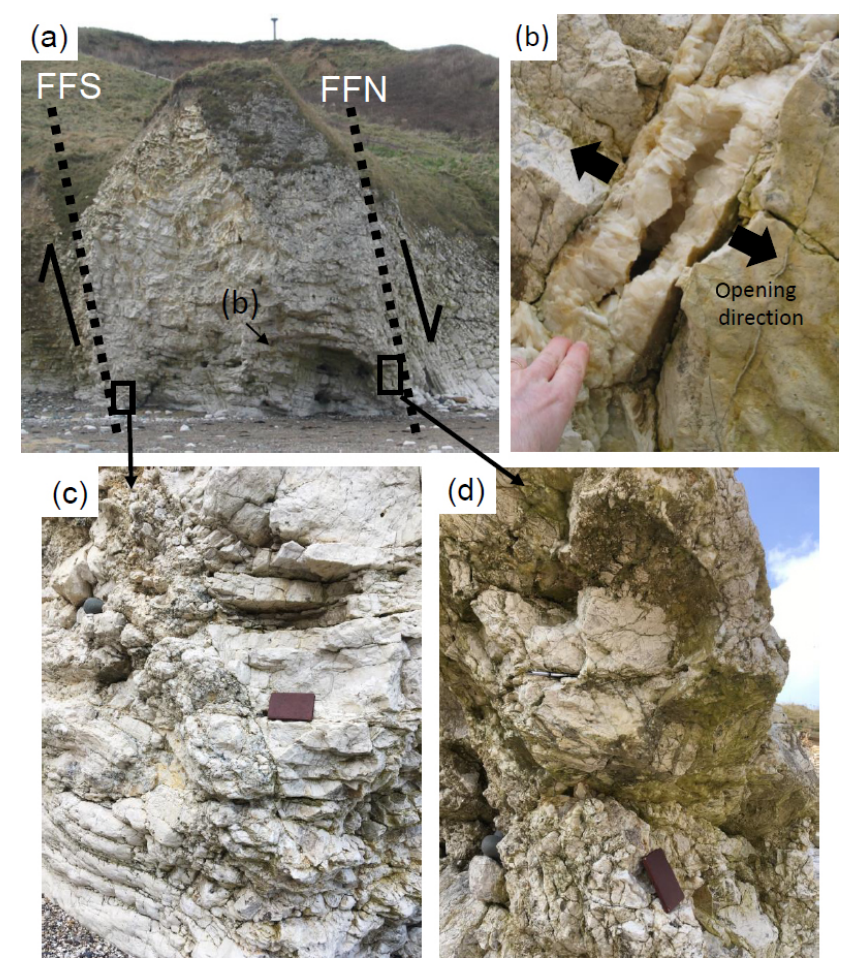

Figure 3. (a) The Frontal Fault North and Frontal Fault South (black dashed lines labelled FFN and FFS, respectively) viewed looking west in the cliffs at Selwicks Bay. The locations of the images in (b)-(d) are shown. (b) Open vuggy tensile vein with partial sparry calcite fill from brecciated region bounded by FFS and FFN. Note the opposite dip to the bounding faults consistent with north-side down motion. (c) Relatively planar fault zone with breccia that forms part of the FFS. Note the gentle drag folding in both hanging wall and footwall consistent with north-side down motion. (d) Wider, more irregular fault breccia that forms part of the FFN, with clasts of wall rocks up to $1.5 \mathrm{~m}$ across.

at high angles, oblique to the fold hinge (Figs. 2f-g, 4d) consistent with the operation of oblique flexural slip processes during folding (e.g. Holdsworth et al., 2002).

The final sample, NR1709, comes from an E-W steeply dipping tensile calcite vein in the densely fractured natural pavement close to the base of North Cliff (Fig. 2h-i; Loc. 4). The structural setting of these veins is seen in the cliffs to the west about half way between Localities 2 and 4, where a steeply S-dipping normal fault with dip-slip slickenlines is seen offsetting an earlier low-angle thrust fault with a centimetre-scale, close-to-tight southward-verging antiform in its immediate hanging wall (Fig. 4a; Loc. 3). Close to the beach at the base of the cliff, E-W subvertical calcite veins identical to those at Locality 4 are seen to be well developed in the immediate hanging wall of the normal fault and show a sense of obliquity consistent with the normal shear sense along the fault (Fig. 4b), suggesting that they are the same age.
In the following sections we first provide the results of our $\mathrm{U}-\mathrm{Pb}$ geochronology, and then, to understand the context of our new dates, we provide field observations and petrographic observations based on thin sections.

\section{$5 \mathrm{U}-\mathrm{Pb}$ geochronology results}

Tera-Wasserburg plots of our new U-Pb data are shown in Fig. 5. NR1707 yielded a lower intercept date of $63.9 \pm$ $2.6 \mathrm{Ma}(\mathrm{MSWD}=2.1)$; this date is from 17 spots from one crystal. NR1708 yielded a lower intercept date of $63.4 \pm$ 5.3 Ma (MSWD = 1.8); this date results from a traverse of one crystal comprising 49 spots. CJ1 is from a localised region of one large calcite crystal, towards its base; 61 spots yielded a date of $54.9 \pm 3.1 \mathrm{Ma}(\mathrm{MSWD}=1.5)$. Two domains of NR1901 were calculated separately. The first domain comprising thin $(<200 \mu \mathrm{m})$ layers of slickenfibre calcite yielded no reasonable date, as the data are dominated by common lead (see Supplement). The second domain comprising a cross-cutting veinlet yielded a date of $58.8 \pm 1.9 \mathrm{Ma}$ $(\mathrm{MSWD}=1.4)$; this date is from 73 spots. NR1709 yielded a lower intercept date of $56.2 \pm 8.2 \mathrm{Ma}(\mathrm{MSWD}=1.6 \mathrm{Ma})$; this result was obtained from two crystals, comprising 51 spots in total. The five successful dates provide a spread in crystallisation of 9 million years, although taking uncertainties into account, this may be as small as 3 million years. The three samples from the frontal fault (NR1708, NR1709, CJ1) do not overlap when considering their age uncertainties, indicating a protracted period of fluid flow of several million years.

\section{Field observations - fracture fills and microstructure}

The contractional and extensional phases of deformation seen in Selwicks Bay are associated with significantly different fault rocks and fracture fills.

\subsection{Contractional structures}

The low-angle thrusts and folds are typically marked by narrow ( $<5 \mathrm{~cm}$ thick) zones of incohesive crush breccia and gouge (Fig. 6a, b), with gouges often best developed where thrust faults interact with clay-rich "marly" interbeds in the chalk. Local gouge injections $<1 \mathrm{~mm}$ thick are seen cutting the wall rocks adjacent to thrusts (Fig. 6b). Calcite mineralisation is largely limited to the development of slickenfibres along exposed thrust planes and bedding planes around metre-scale folds (Figs. 2f, 6d). These slickenfibres show widespread evidence for crack-seal textures and are locally cross-cut by later veinlets of structureless sparry calcite (Fig. 2g). The age of the folding relative to the normal movements along the frontal faults is unclear, as no clear mesoscale cross-cutting relationships are seen, but the folds and thrusts cross-cut by the normal faults at Locality 3 are 

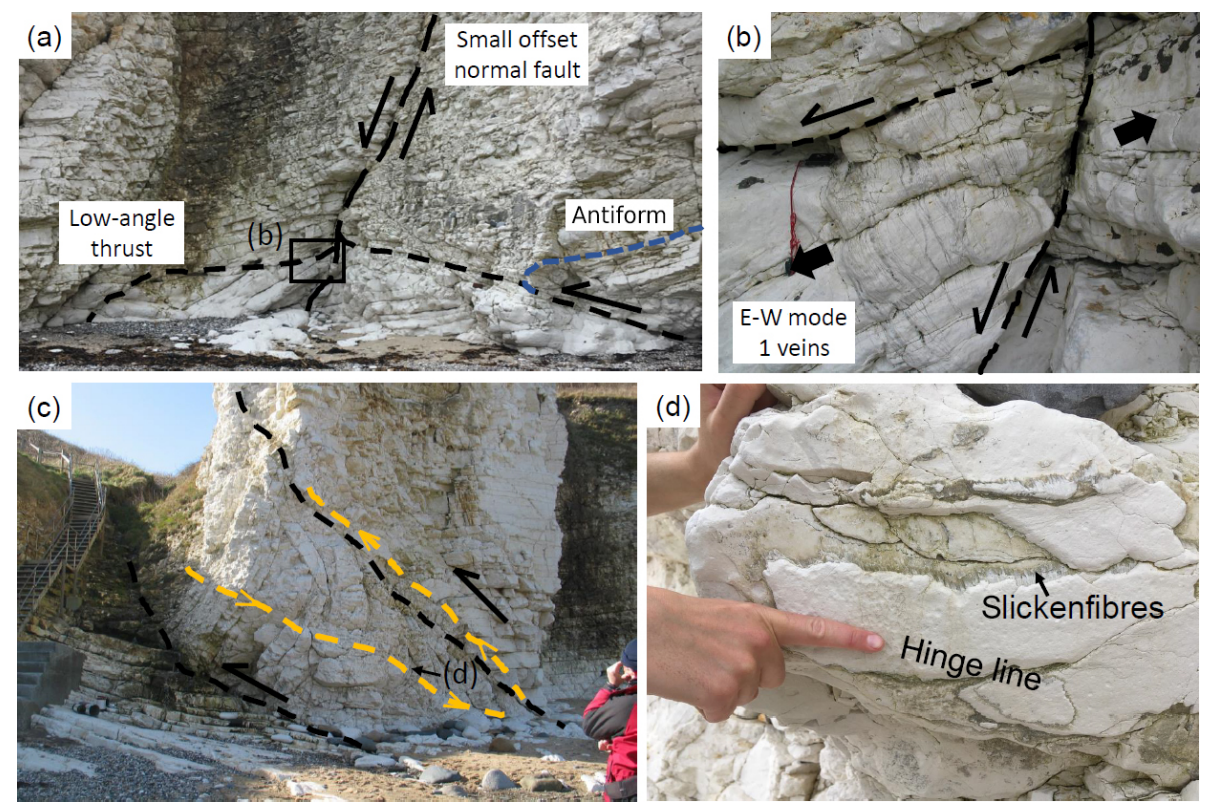

Figure 4. (a) Locality 3 - view looking west of top-to-the-south thrust fault cross-cut by south-side-down, steeply dipping normal fault, north side of Selwicks Bay. Bedding in the hanging wall (blue) of the thrust is deformed by a centimetre-scale, south-overturning anticline. Box shows location of (b). (b) Close-up view of normal fault shown in (a) with north-dipping tensile veins filled with calcite in hanging wall consistent with south-side-down sense of throw. (c) Locality 2 - view looking west of metre-scale, close-to-tight, southward-verging antiform-synform pair (fold axes in yellow) and associated top-to-the-south low-to-moderately north-dipping thrust faults (black dashed lines) some $40 \mathrm{~m}$ north of the FFN. (d) View looking south of exposed synformal fold hinge shown in (c) with bedding-parallel calcite slickenfibres oriented oblique to the fold hinge.

identical in style to those at this last locality. Thus, it is suggested that the main phase of extensional displacement and hydrothermal calcite mineralisation associated with the frontal fault zone likely post-dates an earlier phase of generally top-to-the-S thrusting and folding.

\subsection{Extensional structures}

The fracture fills associated with both the "frontal fault" zone of Starmer (1995) and the small-scale normal faults and associated veins elsewhere in Selwicks Bay are significantly different compared to the earlier contractional features.

Shear fractures have various orientations in the wall rocks, comprising small-offset $(<0.5 \mathrm{~m})$ normal faults with dip-slip slickenlines (Sagi et al., 2016). These are closely associated with steeply dipping to subvertical generally E-W-trending calcite veins filling tensile (Mode I) fractures (e.g. Figs. 3bc, 7a-c; the Group I veins of Faÿ-Gomord et al., 2018). The fills are predominantly fine- to coarse-grained sparry calcite and commonly form as braided, up to $0.5 \mathrm{~m}$ wide zones of veins (e.g. Fig. 3c-d) that resemble the "zebra rocks" described by Holland and Urai (2010) in low-porosity limestones in Oman. Most individual veins have an average thickness of 1-2 mm, but the thickest can (locally) reach widths of up to $30 \mathrm{~cm}$. Many veins are composite, having more than one calcite fill with subtle differences in colour.
Breccia fills are mostly associated with the frontal fault zone (e.g. Figs. 2c-d, 3c-d). The majority are generally E-W- to ENE-WSW-trending, steeply dipping, with clasts dominated by chalk that are clearly derived from the host wall rocks, although differences in texture and colour of individual clasts relative to immediately adjacent wall rocks and other clasts indicate a degree of mixing and displacement from the source. The breccias show every gradation from incipient crackle (Fig. 7a) through mosaic to chaotic textures (Figs. 2c, 7b), with clasts becoming generally more rounded as the fill becomes chaotic (Woodcock and Mort, 2008). Importantly, the fills show very little evidence for shearing or attrition of clasts and closely resemble breccias formed by wall rock collapse and infilling into open tensile fissures in near-surface faulting environments (Woodcock et al., 2006; Holdsworth et al., 2019, 2020).

The breccia matrices are compositionally very variable. Some are clay rich ("marly") and darker coloured, whilst the majority are lighter coloured with less clay and are well cemented by sparry calcite (the Group II veins of Faÿ-Gomord et al., 2018). Generally, E-W-trending calcite veins essentially identical to those seen in the wall rocks are seen to both cross-cut breccia and are also included as clasts in breccia or as earlier misoriented veins cross-cutting chalk clasts (Figs. 2d, 7b). This might suggest that calcite mineralisation, breccia formation and cementation were broadly contempo- 

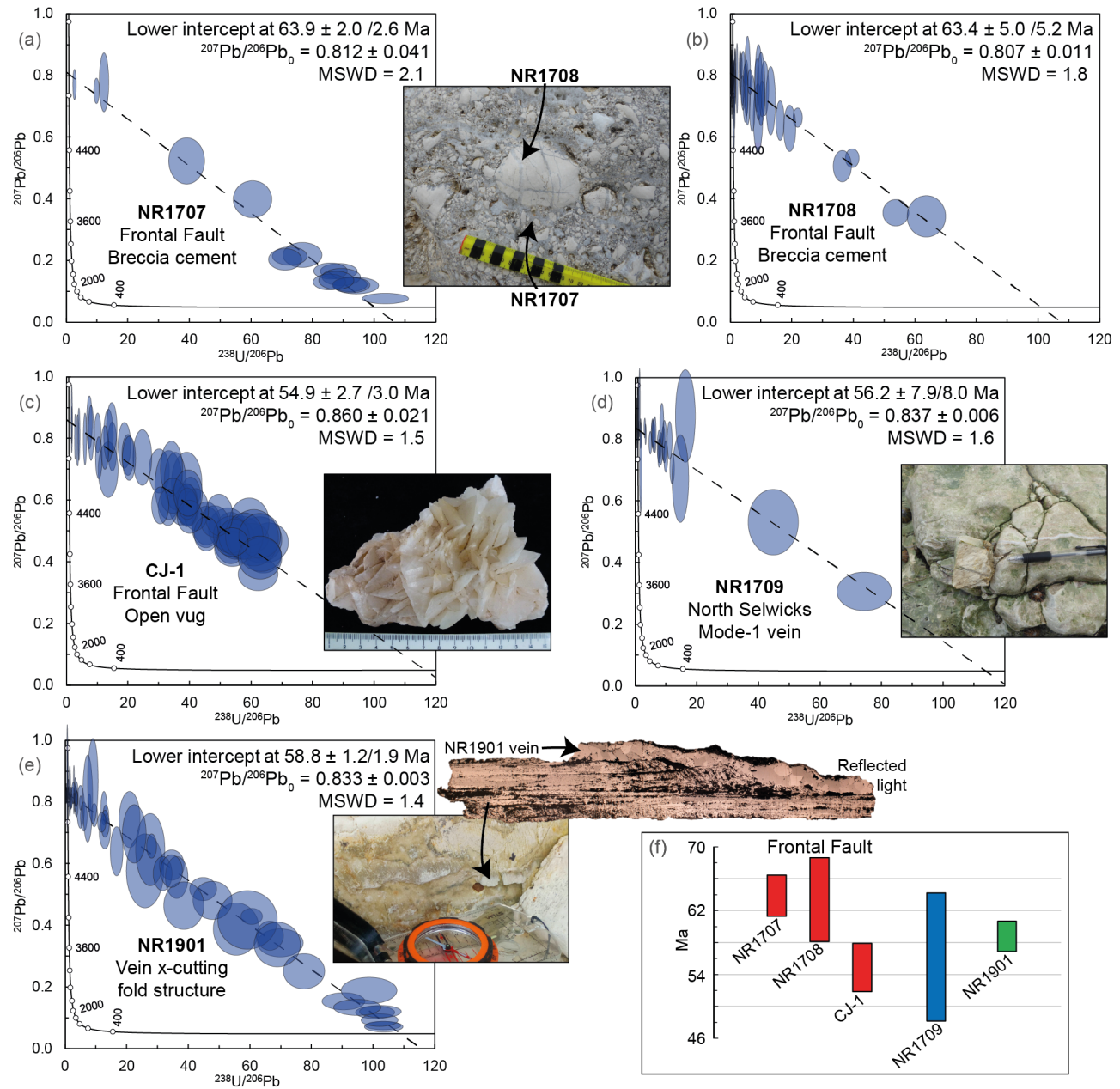

Figure 5. (a-e) Tera-Wasserburg plots of U-Pb results (all uncertainties shown and quoted at $2 \sigma$ ) and corresponding sample images (see text in the Supplement for full size images). (f) Comparison of the five dates plotted with their $2 \sigma$ uncertainties.
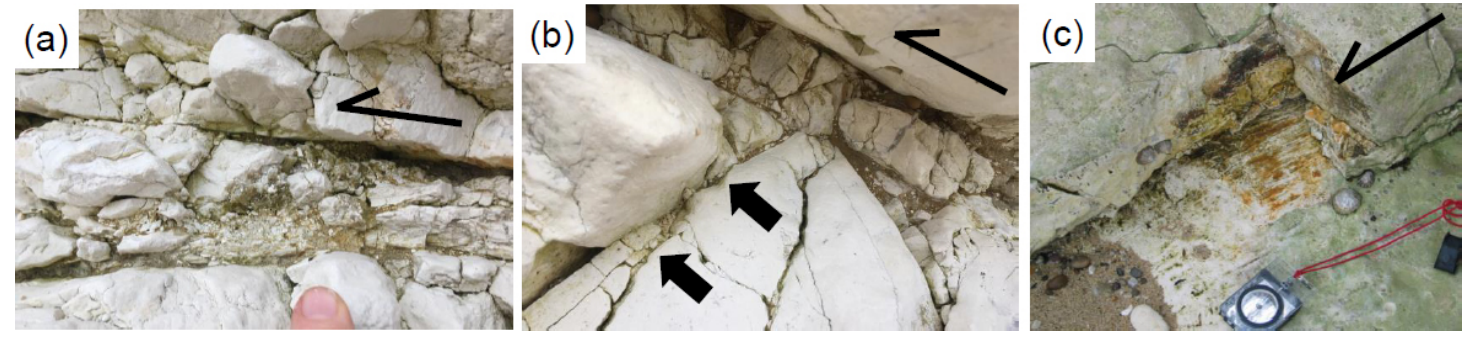

Figure 6. Structures associated with contractional structures in Selwicks Bay; all from Locality 3. (a) Crush breccia along top-to-the-south thrust fault reoriented by later, normal fault-related tilting. (b) Crush breccia and brown gouge derived from chalk and shale, respectively, associated with top-to-the-south thrust fault with narrow gouge injections into footwall, one of which is denoted by an arrow. (c) Calcitehematite slickenlines associated with top-to-the-south thrust fault.

raneous processes. Many veins are composite, having more than one calcite fill with subtle differences in colour; weathering on the foreshore reveals both ferroan calcite (stained red due to oxidation) and non-ferroan calcite (unstained) fills (Fig. 7c), implying changing fluid chemistry during the period of fracture-fill mineralisation.
A notable feature of the locally later tensile calcite vein fills (Group III veins of Faÿ-Gomord et al., 2018) is the widespread development of vuggy cavities (Figs. $3 \mathrm{~b}$ and 7b); these are particularly widespread in the frontal fault zone. Their development implies that in the latter stages of vein filling at least, rates of mineral precipitation were reduced 


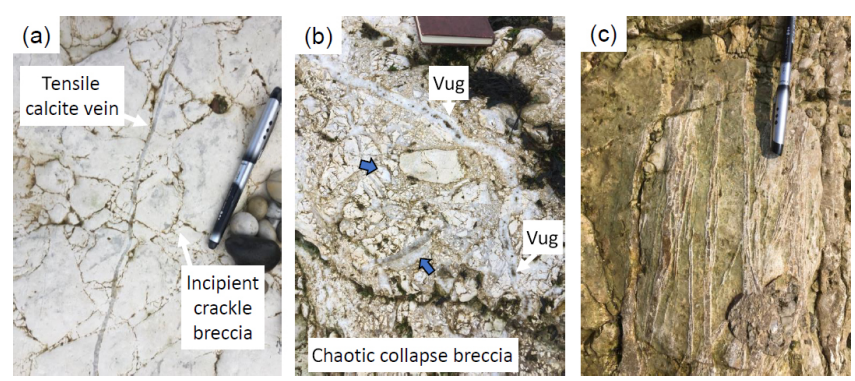

Figure 7. Breccia development associated with extensional movements along the frontal fault zone in Selwicks Bay in the region bounded by the FFS and FFN; all photos are from the foreshore. (a) Incipient crackle breccia development (plan view) looking at a bedding plane in chalk that is cross-cut by a narrow calcite-filled tensile vein. (b) Cross-section view of typical chaotic collapse breccia with little evidence for shearing or attrition of clasts. Note that calcite veins occur in clasts (examples as arrows) and as crosscutting later vuggy features (labelled vug). (c) Composite calcite veins in plan view from foreshore below high tide with younger orange-stained ferroan calcite and older white non-ferroan calcite rims.

relative to fracture opening rates, implying that fractures remained open for protracted periods of time.

Further evidence for the development of long-lived open fissures in the frontal fault zone comes from the preservation of brown-coloured marly breccias and sediment fills in tensile fissures (Fig. 8a-d). These occur as subvertical features that both post-date and predate adjacent subparallel calcite veins (Fig. 8a and b, respectively) and in steeply inclined fissures that obliquely cross-cut adjacent veins (Fig. 8c). More rarely, irregular subhorizontal zones of fine marly sediment fill the lower part of fractures that cross-cut earlier calcite veins, whilst the upper part of the cavity is filled with later calcite (Fig. 8d). These sediments are crudely bedded and represent geopetal structures that consistently become younger upwards wherever they are found.

Thin sections reveal that the majority of calcite veins are syntaxial and sparry (Fig. 9a). The marly breccias and sediment fills contain numerous fragments of wall rock chalk, earlier calcite vein fills and more exotic materials such as brown clays, chert, individual microfossils - including sponge spicules - and rounded grains of both quartz and glauconite (Fig. 9b-d). The geopetal fills preserve striking examples of graded bedding (Fig. 9a and e) and cockade style mineralisation textures (Fig. 9f), with fine-grained, graded suspensions of sedimentary grains floating in single crystals of calcite cement grown in perfect optical continuity with adjacent vein fills (Fig. 9a, e, and f). The preservation of such features suggest that sedimentary material was transported by flowing fluids into open cavities connected to the surface and that cementation associated with contemporaneous hydrothermal mineralisation "froze" the finer materials in place before they were able to settle out of suspension (cf. Wright et al., 2009; Frenzel and Woodcock, 2014).

In summary, most but not all of the calcite mineralisation seen at Selwicks Bay is related to extensional structures that locally appear to post-date an earlier phase of centimetre- to metre-scale top-to-the-S folding and thrusting. Mineral veins are predominantly tensile and generally $\mathrm{E}-\mathrm{W}$ trending and appear to be broadly contemporaneous with the development of calcite-mineralised breccias along the frontal fault zone. The breccias preserve widespread textures consistent with wall rock collapse into open cavities rather than being the product of attritional cataclasis. The existence of long-lived open fissures is confirmed by the widespread preservation of vuggy textures and cockade-style calcite mineralisation, together with the local development of marly sediment fills and geopetal structures. Based on the large amount of calcite mineralisation - especially along the frontal fault zone - it is clear that substantial volumes of fluid flow have been localised along this fault zone during extension (Sagi et al., 2016).

\section{Discussion}

\subsection{The timing of deformation at Selwicks Bay}

The dates obtained from the five samples yield constraints on the timing of deformation at Selwicks Bay. NR1707 and NR1708 (Loc. 1) are inferred to directly date the extensional phase of deformation (normal faulting) along the frontal fault zone, as they are from regions of calcite veining and cemented collapse breccias. These samples provide overlapping dates of 63.9 and $63.4 \mathrm{Ma}$. $\mathrm{CJ} 1$ is also from the frontal front zone but yields a younger date of $54.9 \mathrm{Ma}$ that is outside of analytical uncertainty of the breccia samples. This younger date is from a relatively late large vuggy fracture fill. We cannot be certain whether this younger date reflects a later fracture-opening event, but there are no clear field or thin section relationships observed to suggest this. NR1709 (Loc. 4) has a large uncertainty, overlapping both the breccia and younger vuggy calcite from the frontal fault. The date indicates that fracture opening at the northern part of Selwicks Bay overlaps that of the frontal fault in the southern part of the bay. The dated late veinlet within sample NR1901 (Loc. 2) overlaps the dates of the other samples (except NR1707). Since this veinlet cross-cuts the flexural folding-related slickenfibre growth, this date provides a lower boundary for the timing of the folding and associated contractional-transpressional deformation.

\subsection{Implications for chalk-hosted fluid flow}

Chalk is an important aquifer for groundwater, particularly in parts of Britain and surrounding countries in Europe (e.g. Price, 1987; MacDonald and Allen, 2001). Chalk can also act as both reservoirs and seals for hydrocarbons (e.g. Hardman, 

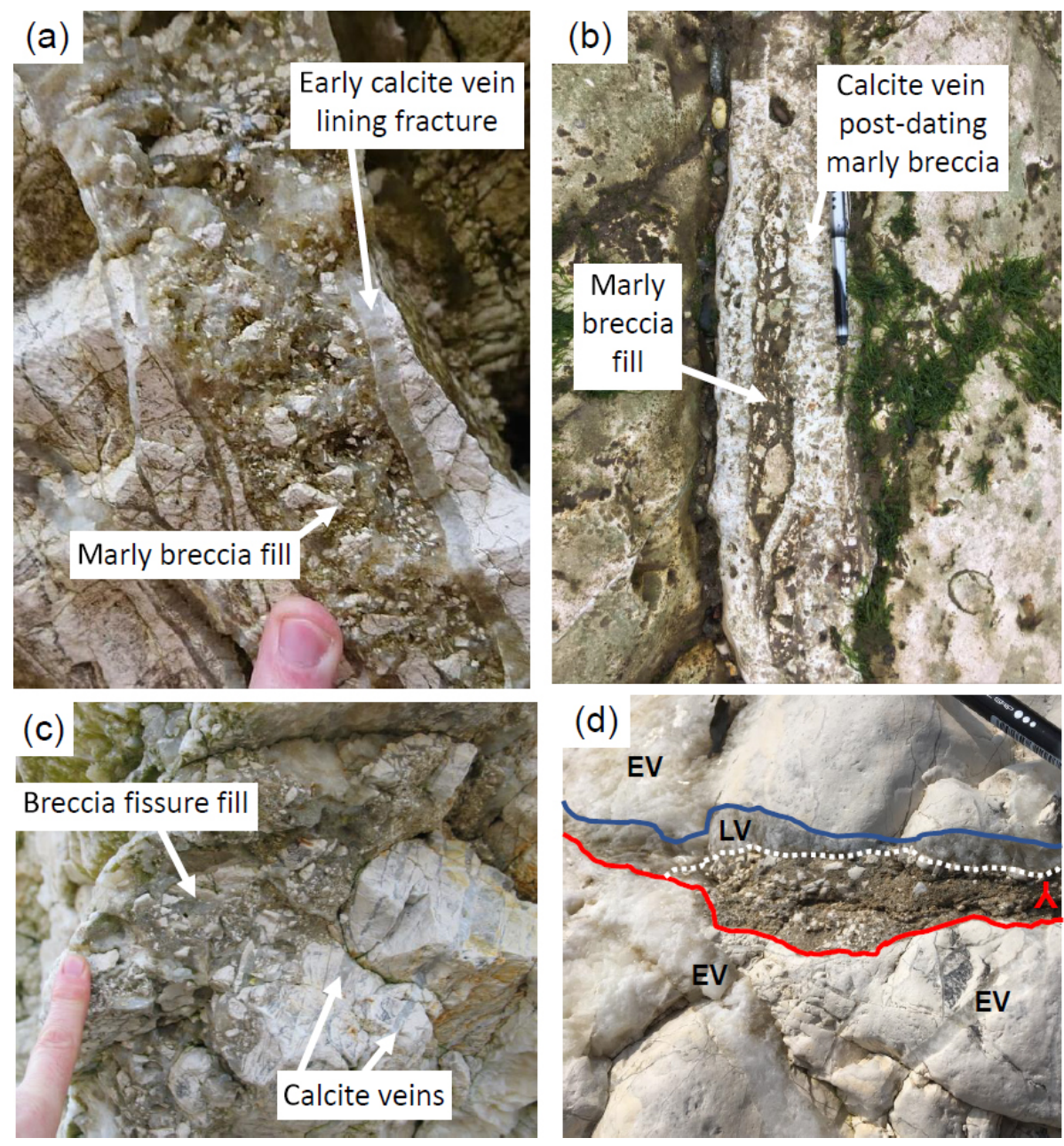

Figure 8. Brown-coloured marly breccias and sediment fills in tensile fissures associated with the frontal fault zone, Selwicks Bay; photos (a) and (c) from the cliff, and (b) and (d) from the adjacent foreshore. (a) Marly breccia fill in cross-section view that post-dates subparallel calcite veins that line fracture. (b) Marly breccia that predates calcite-cemented breccia in plan view. (c) Steeply inclined fissure fill in crosssection view that obliquely cross-cuts adjacent calcite veins. (d) Oblique view of irregular subhorizontal zone of fine marly sediment filling the lower part of a fracture that cross-cuts an earlier calcite vein (EV), whilst the upper part of the cavity is filled by a later calcite vein (LV). The sediment is crudely bedded and forms a geopetal fill that becomes younger upwards, as indicated by the inverted Y symbol.

1982; Mallon and Swarbrick, 2008). As such, the timing and origin of fracture-hosted permeability is an important constraint on understanding fluid flow through chalk.

The frontal fault zone structure at Selwicks Bay represents a significant damage zone associated with normal faulting in the region. This fault zone forms part of the FHFZ but has much less offset than other fault zones to the north (Bempton Fault) and south (Langtoft Fault) (Fig. 1a-b). It is clear, however, that the large fissure systems forming the fault zone have acted as a major fluid conduit, allowing voluminous fluid flow through the chalk, possibly over a long time period of at least 5 million years. Geochemical analyses of the calcite fills by Faÿ-Gomord et al. (2018) show that all the calcite veins share broadly the same chemical signature, which they link to an underlying source of meteoric fluids in the Triassic Sherwood Sandstone. However, their salinity data vary, suggesting some mixing with saline fluids. Given the development of open vugs and geopetal sediment fills with glauconite and microfossil fragments, we propose that the fluid pathways were linked to a surface marine environment at the time of calcite mineralisation. The development of contemporaneous open fissures with sediment infilling due to wall rock collapse and washing-in of finer materials from the surface, together with hydrothermal mineralisation sourced from below, and occurring during tectonic extension, is an increasingly recognised phenomenon in near-surface fracture systems $(<1-2 \mathrm{~km}$ depth; e.g. Wright et al., 2009; Walker et al., 2011; Holdsworth et al., 2019, 2020; Hardman et al., 2020).

We suggest that the fault has acted as a "fluid superhighway", connecting deeper reservoir units (Triassic sandstones) with the surface during the Palaeocene to early Eocene. The 

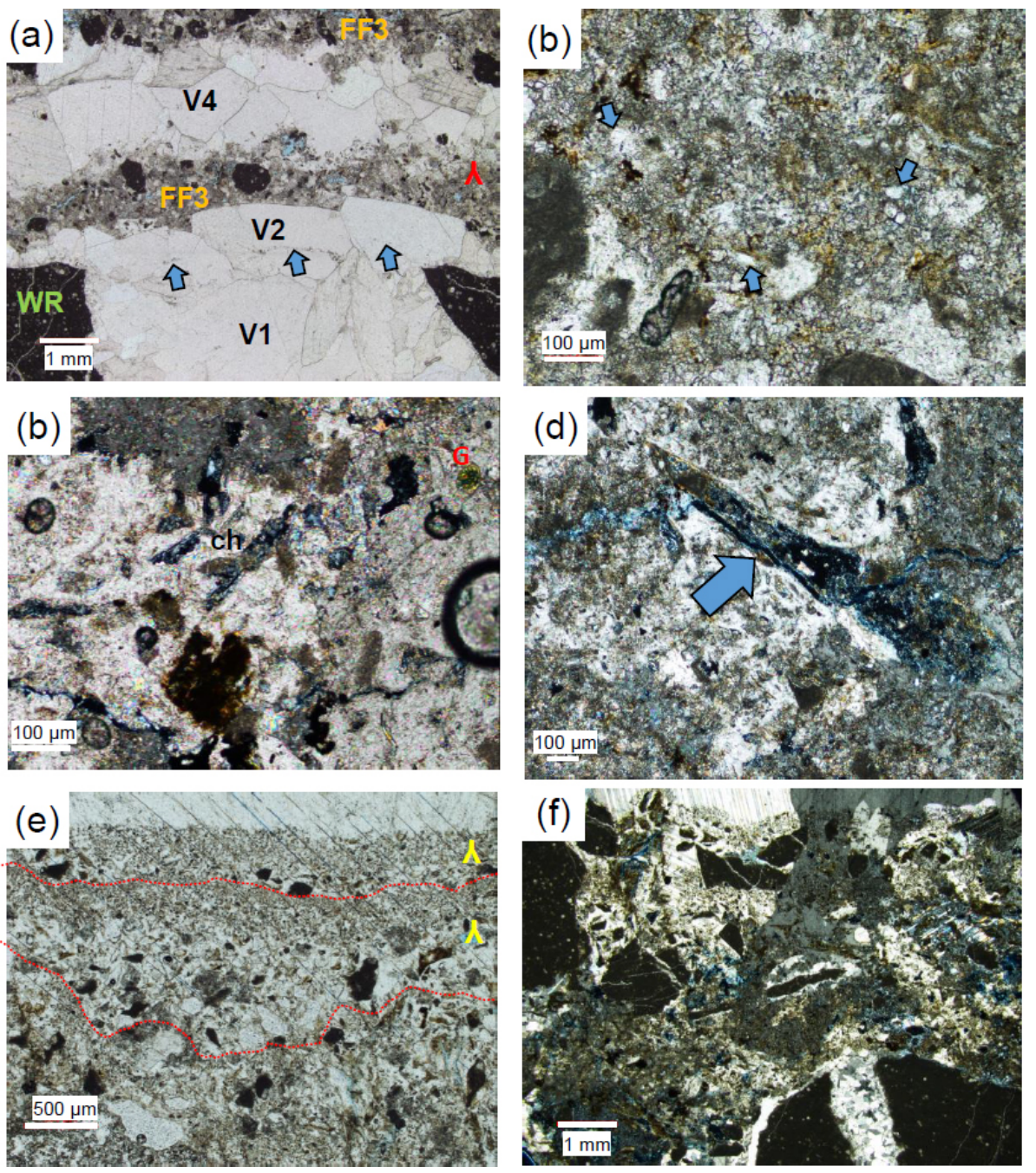

Figure 9. Thin sections of sediment fills from Selwicks Bay Frontal Fault Zone taken in plane polarised light unless indicated otherwise. (a) Chalk wall rocks (WR) and earlier calcite vein fills (V1, V2) unconformably overlain by sediment fill (FF3) cut by slightly later vein (V4); note that the mineral cement in the graded sediment grows in optical continuity with the V4 vein. Note also the line of inclusions separating V1 and V2. (b) Details of calcite-cemented sediment fill showing dark wall-rock clasts, hematite staining, clastic quartz grains (arrows) and pale subangular clasts of earlier calcite. (c-d) As (b), showing included clasts of chert (ch) and glauconite (G) and sponge spicule (arrows). (e-f) Cockade-style cementation of graded or complex sediment fills where the calcite cements are in optical continuity with the overlying vein fills. Panel (f) is taken with crossed polars.

existence of a fluid conduit of this kind potentially has major implications for storage and migration processes associated with reservoirs, whether they be for groundwater or hydrocarbons. Importantly, this structure is potentially of subseismic scale, indicating that even subseismic features may host large-scale fluid flow and produce significant conduits that exhibit high permeability over protracted time periods lasting millions of years. We should also point out that this is just one fault of many in the FHFZ and that many of the faults exposed inland are also associated with extensive veining, as well as secondary cementation of the chalk adjacent to the faults. These secondary cements form hard chalk zones, which then potentially act as barriers to fluid flow.

\subsection{Implications for regional tectonics}

The Flamborough Head Fault Zone forms a structural boundary that separates the Cleveland Basin to the north and the Market Weighton Block to the south (Kirby and Swallow, 1987; Starmer, 1995). The history of the fault zone is thought to be influenced by the subsidence and later inversion of the Cleveland Basin, whilst the Market Weighton Block remained high and stable (Kent, 1980). The Flamborough Head Fault Zone is truncated to the east by several intersecting deformation zones (Central Fracture Zone, Dowsing Fault Zone, Sole Pit Basin; see Fig. 1) and truncated on land by the Hunmanby Trough-Peak Fault Zone (see Fig. 1). The 
deformation that led to the formation and inversion of these basins has a long history extending from the Permo-Triassic to the Miocene (e.g. Starmer, 1995, and references therein), and the far-field stress associated with their formation may have some relevance to the Flamborough Head Fault Zone. The histories of these offshore regions are only constrained by seismic and borehole data and correlation with known regional events. Therefore, dating of onshore structures such as those presented in the current study provides additional and new absolute timing constraints on the structural evolution at a regional scale.

There have been long-standing differences in the interpretations of the structural complexity of deformation in the Flamborough Head region. Some prefer a polyphase deformation sequence over a protracted time period from the later Cretaceous to Neogene times (e.g. Starmer, 1995, and references therein), whilst others favour a somewhat simpler regime involving shorter-lived periods of strike-slip tectonics and polymodal or polygonal extensional faulting (e.g. Peacock and Sanderson, 1994; Sagi et al., 2016; Faÿ-Gomord et al., 2017).

Our findings show that at Selwicks Bay, and by inference, along the FHFZ, a regionally significant extensional phase of deformation occurred over a protracted period during the earliest Palaeocene to early Eocene times (ca. 64-55 Ma). Our field observations suggest that this represents the youngest phase of deformation along the frontal fault zone - and by inference the FHFZ - post-dating any contractional or transpressional deformation. It should be noted that we cannot rule out that fluid flow and tensile fracturing may have extended to even younger dates than our study implies. Interestingly, this timing of deformation overlaps with, but is broadly younger than, the estimated Late Cretaceous timing of widespread inversion and tectonic events across parts of NW Europe, discussed by Mortimore (2018).

The age ranges for calcite mineralisation are almost exactly coeval with the timing of igneous activity in western Scotland and Northern Ireland, related to mantle upwelling forming the British Palaeogene Igneous Province (Jolley and Bell, 2002) and associated regional uplift (Lewis, 1992; Nadin et al., 1997). In particular, a clear temporal link exists between the calcite mineralisation and the intrusion of the nearby Cleveland Dyke, the easternmost exposure of which lies some $30 \mathrm{~km} \mathrm{NW}$ of Selwicks Bay (Fig. 1a). The intrusion of this dyke - which can be traced across a wide region of northern Britain - is thought to be ca. 58-55 Ma based on K-Ar dating (Fitch et al., 1978; Evans et al., 1973). Our findings therefore open up the intriguing possibility that extension and associated fluid flow in the Flamborough Head region are related to the far-field influence of North Atlantic opening processes.

Our findings further suggest that folding and thrusting of the chalk at Flamborough Head must be older than ca. $64 \mathrm{Ma}$. Given the Santonian age of the youngest chalk affected by deformation (ca. 86-72 Ma; Whitham, 1993; Mor- timore, 2019), this implies that the inversion event can be no older than latest Cretaceous. In previous interpretations, much of the late stage compressional deformation along the FHFZ has been linked to inversion related to the far-field effects of the Alpine orogeny during the Neogene (Starmer, 1995). Clearly, our findings from Selwicks Bay cast significant doubt on this model. It seems possible that the earlier folding and thrusting seen at Selwicks Bay and elsewhere around Flamborough Head is related to a phase of strikeslip deformation along the FHFZ. Based on our findings to date, we cannot rule out the possibility that these strike-slip events overlap with the later extensional deformation; i.e. they are all manifestations of a protracted phase of regional transtensional tectonics in latest Cretaceous to Palaeocene times. Thickness changes in the chalk around the faults exposed at Flamborough Head (see Mortimore, 2019, and references therein) are the only current evidence for extensional deformation occurring earlier than our oldest date of $64 \mathrm{Ma}$.

We propose that a careful reassessment of the deformation structures and sequences in the onshore and offshore regions around Flamborough Head is required, ideally with further absolute dating and palaeostress inversion analyses. More generally, our findings are a further illustration that the sequence, timing and tectonic significance of the Cenozoic history of the British Isles is in need of significant reassessment (e.g. see discussion in Parrish et al., 2018).

\section{Conclusions}

$\mathrm{U}-\mathrm{Pb}$ dating of calcite vein fill from Selwicks Bay provides constraints on the timing of faulting. Five dates, ranging from 63.9 to $54.9 \mathrm{Ma}$, indicate that formation of the mineralised collapse breccia within the extensional frontal fault zone occurred at ca. $63 \mathrm{Ma}$, with fluid flow continuing to at least $55 \mathrm{Ma}$. Calcite from a Mode I tensile vein in the nearby wall rocks has a large age uncertainty but overlaps both these dates. A veinlet cross-cutting slickenfibres formed on a bedding parallel surface of a fold structure places a lower boundary on folding at $56 \mathrm{Ma}$. The dates indicate that faulting within the Flamborough Head Fault Zone was Palaeocene in age. As an alternative to the polyphase compressional and extensional model of Starmer (1995), we instead suggest that, except for the possibility of synsedimentary slump structures (Mortimore, 2019), a more straightforward model involving overlapping strike-slip and extensional deformation may explain much if not all of the deformation at Selwicks Bay. Our study has shown that the extensional frontal fault zone at Selwicks Bay represents the following: (1) a fault-hosted fluid conduit that linked deeper sedimentary units to the shallow subsurface and hosted voluminous fluid flow over a protracted timescale and (2) that its fault activity occurred within a 5-10 Ma time frame, overlapping with that of the intrusion of the nearby Cleveland Dyke (ca. 58-55 Ma), the development of the North Atlantic Igneous Province and the regional 
uplift of NW Britain related to the opening of the North Atlantic.

Code and data availability. $\mathrm{U}-\mathrm{Pb}$ data are presented in the table in the Supplement, along with the corresponding methods and analytical details in the text in the Supplement.

Supplement. The supplement related to this article is available online at: https://doi.org/10.5194/se-11-1931-2020-supplement.

Author contributions. NMWR and JKL collected the analytical data. NMWR, ARF, JKL, CJ and REH conducted fieldwork and sample collection. NMWR, JKL and REH conducted sample imaging and petrography. All authors contributed to writing the paper.

Competing interests. The authors declare that they have no conflict of interest.

Special issue statement. This article is part of the special issue "Faults, fractures, and fluid flow in the shallow crust". It is not associated with a conference.

Acknowledgements. Nick M. W. Roberts, Andrew R. Farrant and Richard Haslam publish with the permission of the executive director of the British Geological Survey. Jack K. Lee acknowledges receipt of a NERC/BGS studentship. The authors thank Mark Woods for discussion and Catherine Mottram and Nigel Woodcock for their constructive reviews.

Financial support. This research has been supported by the UK Natural Environment Research Council (grant no. NE/S011587/1).

Review statement. This paper was edited by Fabrizio Balsamo and reviewed by Catherine Mottram and Nigel Woodcock.

\section{References}

Ault, A. K., Frenzel, M., Reiners, P. W., Woodcock, N. H., and Thomson, S. N.: Record of paleofluid circulation in faults revealed by hematite (U-Th)/He and apatite fission-track dating: An example from Gower Peninsula fault fissures, Wales, Lithosphere, 8, 379-385, 2016.

Beaudoin, N., Lacombe, O., Roberts, N. M., and Koehn, D.: U-Pb dating of calcite veins reveals complex stress evolution and thrust sequence in the Bighorn Basin, Wyoming, USA, Geology, 46, 1015-1018, 2018.

Bergemann, C. A., Gnos, E., Berger, A., Whitehouse, M. J., Mullis, J., Walter, F., and Bojar, H. P.: Constraining long-term fault ac- tivity in the brittle domain through in situ dating of hydrothermal monazite, Terra Nova, 30, 440-446, 2018.

Blundell, D. J.: Cenozoic inversion and uplift of southern Britain, in: Exhumation of the North Atlantic margin: Timing, Mechanisms and Implications for Petroleum Exploration, edited by: Doré, A. G., Cartwright, J. A., Stoker, M. S., Turner, J. P., and White, N., Geological Society, London, Special Publications, 196, 85-101, 2002.

Chadwick, R. A.: Aspects of basin inversion in southern Britain, J. Geol. Soc., 150, 311-322, 1993.

Dichiarante, A. M., Holdsworth, R. E., Dempsey, E. D., Selby, D., McCaffrey, K. J. W., Michie, U. M., Morgan, G., and Bonniface, J.: New structural and Re-Os geochronological evidence constraining the age of faulting and associated mineralization in the Devonian Orcadian Basin, Scotland, J. Geol. Soc., 173, 457-473, 2016.

Emery, A.: Palaeopressure reconstruction to explain observed natural hydraulic fractures in the Cleveland Basin, Mar. Petrol. Geol., 77, 535-552, 2016.

Evans, A. L., Fitch, F. J., and Miller, J. A.: Potassium-argon age determinations on some British Tertiary igneous rocks, J. Geol. Soc., 129, 419-438, 1973.

Farrant, A. R., Woods, M. A., Maurice, L., Haslam, R., Raines, M., and Kendall, R.: Geology of the Kilham area and its influence on groundwater flow, British Geological Survey commissioned report CR/16/023, British Geological Survey, Keyworth, 2016.

Faÿ-Gomord, O., Allanic, C., Verbiest, M., Lasseur, E., Swennen, R., and Gauthier, B.: Synsedimentary Polygonal Faults System in Tight Chalk: Multiscale Evidence From Outcrop, Flamborough Head (UK), in: 79th EAGE Conference and Exhibition 2017, June 2017, 1, 1-5, EAGE Publications, the Netherlands, 2017.

Faÿ-Gomord, O., Allanic, C., Verbiest, M., Honlet, R., Champenois, F., Bonifacie, M., Chaduteau, C., Wouters, S., Muchez, P., Lasseur, E., and Swennen, R.: Understanding Fluid Flow during Tectonic Reactivation: An Example from the Flamborough Head Chalk Outcrop (UK), Geofluids, 2018, 9352143, https://doi.org/10.1155/2018/9352143, 2018.

Fitch, F. J., Hooker, P. J., Miller, J. A., and Brereton, N. R.: Glauconite dating of Palaeocene-Eocene rocks from East Kent and the time-scale of Palaeogene volcanism in the North Atlantic region, J. Geol. Soc., 135, 499-512, 1978.

Frenzel, M. and Woodcock, N. H.: Cockade breccia: Product of mineralisation along dilational faults, J. Struct. Geol., 68, 194206, 2014.

Goodfellow, B. W., Viola, G., Bingen, B., Nuriel, P., and KylanderClark, A. R.: Palaeocene faulting in SE Sweden from U-Pb dating of slickenfibre calcite, Terra Nova, 29, 321-328, 2017.

Hansman, R. J., Albert, R., Gerdes, A., and Ring, U.: Absolute ages of multiple generations of brittle structures by $\mathrm{U}-\mathrm{Pb}$ dating of calcite, Geology, 46, 207-210, 2018.

Hardman, K., Holdsworth, R. E., Dempsey, E., and McCaffrey, K.: The nature and significance of rift-related, near-surface fissure fill networks in fractured carbonates below regional unconformities, J. Geol. Soc., https://doi.org/10.1144/jgs2020-074, online first, 2020.

Hardman, R. F. P.: Chalk reservoirs of the North Sea, B. Geol. Soc. Denmark, 30, 119-137, 1982.

Hill, C. A., Polyak, V. J., Asmerom, Y., and Provencio, P.: Constraints on a Late Cretaceous uplift, denudation, and incision of 
the Grand Canyon region, southwestern Colorado Plateau, USA, from U-Pb dating of lacustrine limestone, Tectonics, 35, 896906, 2016.

Holdsworth, R. E., Tavarnelli, E., Clegg, P., Pinheiro, R. V. L., Jones, R. R., and McCaffrey, K. J. W.: Domainal deformation patterns and strain partitioning during transpression: an example from the Southern Uplands terrane, Scotland, J. Geol. Soc., 159, 401-415, 2002.

Holdsworth, R. E., McCaffrey, K. J. W., Dempsey, E., Roberts, N. M. W., Hardman, K., Morton, A., Feely, M., Hunt, J., Conway, A., and Robertson, A.: Natural fracture propping and earthquakeinduced oil migration in fractured basement reservoirs, Geology, 47, 700-704, 2019.

Holdsworth, R. E., Trice, R., Hardman, K., McCaffrey, K. J. W., Morton, A., Frei, D., Dempsey, E., Bird, A., Rogers, S.: The nature and age of basement host rocks and fissure fills in the Lancaster field fractured reservoir, West of Shetland, J. Geol. Soc., 177, 1057-1073, 2020.

Holland, M. and Urai, J. L.: Evolution of anastomosing crack-seal vein networks in limestones: Insight from an exhumed highpressure cell, Jabal Shams, Oman Mountains, J. Struct. Geol., 32, 1279-1290, 2010.

Horstwood, M. S., Košler, J., Gehrels, G., Jackson, S. E., McLean, N. M., Paton, C., Pearson, N. J., Sircombe, K., Sylvester, P., Vermeesch, P., and Bowring, J. F.: Community-derived standards for LA-ICP-MS U-(Th-) Pb geochronology-Uncertainty propagation, age interpretation and data reporting, Geostand. Geoanal. Res., 40, 311-332, 2016.

Jeans, C. V.: The Market Weighton Structure: tectonics, sedimentation and diagenesis during the Cretaceous, P. Yorks. Geol. Soc., 39, 409-444, 1973.

Jolley, D. W. and Bell, B. R.: The evolution of the North Atlantic Igneous Province and the opening of the NE Atlantic rift, in: The North Atlantic Igneous Province: Stratigraphy, Tectonic, Volcanic and Magmatic Processes, edited by: Jolley, D. W. and Bell, B. R., Geological Society, London, Special Publications, 197, 113, 2002.

Kent, P. E.: Subsidence and uplift in East Yorkshire and Lincolnshire: a double inversion, P. Yorks. Geol. Soc., 42, 505-524, 1980.

Kent, P. E., Raynor, D. H., and Hemingway, J. E.: Structural history. The Geology and Mineral Resources of Yorkshire, Yorkshire Geological Society Occasional Publication, 2, 13-28, 1974.

Kirby, G. A. and Swallow, P. W.: Tectonism and sedimentation in the Flamborough Head region of north-east England, P. Yorks. Geol. Soc., 46, 301-309, 1987.

Kirby, G. A., Smith, K., Smith, N. J. P., and Swallow, P. W.: Oil and Gas generation in eastern England, in: Petroleum Geology of Northwest Europe, edited by: Brooks, J. and Glennie, K., Graham and Trotman, London, 171-180, 1987.

Lamplugh, G. W.: Notes on the White Chalk of Yorkshire, Parts I. and II, P. Yorks. Geol. Soc., 13, 65-87, 1895.

Lewis, C. L., Green, P. F., Carter, A., and Hurford, A. J.: Elevated K/T palaeotemperatures throughout Nortwest England: three kilometres of Tertiary erosion?, Earth Planet. Sc. Lett., 112, 131-145, 1992.

Ludwig, K. R.: User's manual for Isoplot 4.15: A geochronological toolkit for Microsoft Excel, Berkeley Geochronology Center, Berkeley, California, USA, 2011.
MacDonald, A. M. and Allen, D. J.: Aquifer properties of the Chalk of England, Q. J. Eng. Geol. Hydroge., 34, 371-384, 2001.

Mallon, A. J. and Swarbrick, R. E.: A compaction trend for nonreservoir North Sea Chalk, Mar. Petrol. Geol., 19, 527-539, 2002.

Mortimore, R. N.: Late Cretaceous tectono-sedimentary events in NW Europe, P. Geologist. Assoc., 129, 392-420, 2018.

Mortimore, R. N.: Late Cretaceous to Miocene and Quaternary deformation history of the Chalk: Channels, slumps, faults, folds and glacitectonics, P. Geologist. Assoc., 130, 27-65, 2019.

Nadin, P. A., Kusznir, N. J., and Cheadle, M. J.: Early Tertiary plume uplift of the North Sea and Faeroe-Shetland basins, Earth Planet. Sc. Lett., 148, 109-127, 1997.

Nuriel, P., Weinberger, R., Kylander-Clark, A. R. C., Hacker, B. R., and Craddock, J. P.: The onset of the Dead Sea transform based on calcite age-strain analyses, Geology, 45, 587-590, 2017.

Nuriel, P., Craddock, J., Kylander-Clark, A. R., Uysal, T., Karabacak, V., Dirik, R. K., Hacker, B. R., and Weinberger, R.: Reactivation history of the North Anatolian fault zone based on calcite age-strain analyses, Geology, 47, 465-469, 2019.

Nuriel, P., Wotzlaw, J. F., Ovtcharova, M., Vaks, A., Stremtan, C., Šala, M., Roberts, N. M. W. and Kylander-Clark, A. R.,: The use of ASH-15 flowstone as a matrix-matched reference material for laser-ablation U-Pb geochronology of calcite, Geochronology Discuss., https://doi.org/10.5194/gchron-2020-22, in review, 2020.

Parrish, R. R., Parrish, C. M., and Lasalle, S.: Vein calcite dating reveals Pyrenean orogen as cause of Paleogene deformation in southern England, J. Geol. Soc., 175, 425-442, 2018.

Peacock, D. C. P. and Sanderson, D. J.: Strain and scaling of faults in the chalk at Flamborough Head, UK, J. Struct. Geol., 16, 97107, 1994.

Phillips, J.: Illustrations of the Geology of Yorkshire; Part 1 - the Yorkshire Coast, London, Thomas Wilson and Sons, York, 1829.

Powell, J. H.: Jurassic sedimentation in the Cleveland Basin: a review, P. York. Geol. Soc., 58, 21-72, 2010.

Price, M.: Fluid flow in the Chalk of England, in: Fluid Flow in Sedimentary Basins and Aquifers, edited by: Goff, J. C. and Williams, B. P. J., Geological Society, London, Special Publications, 34, 141-156, 1987.

Rawson, P. F. and Wright, J. K.: The Yorkshire Coast (No. 34), Geologists' Association, London, 2000.

Ring, U. and Gerdes, A.: Kinematics of the Alpenrhein-Bodensee graben system in the Central Alps: Oligocene/Miocene transtension due to formation of the Western Alps arc, Tectonics, 35, 1367-1391, 2016.

Roberts, N. M. W. and Walker, R. J.: U-Pb geochronology of calcite-mineralized faults: Absolute timing of rift-related fault events on the northeast Atlantic margin, Geology, 44, 531-534, 2016.

Roberts, N. M. W., Rasbury, E. T., Parrish, R. R., Smith, C. J., Horstwood, M. S., and Condon, D. J.: A calcite reference material for LA-ICP-MS U-Pb geochronology, Geochem. Geophy. Geosy., 18, 2807-2814, 2017.

Roberts, N. M. W., Drost, K., Horstwood, M. S. A., Condon, D. J., Chew, D., Drake, H., Milodowski, A. E., McLean, N. M., Smye, A. J., Walker, R. J., Haslam, R., Hodson, K., Imber, J., Beaudoin, N., and Lee, J. K.: Laser ablation inductively coupled plasma mass spectrometry (LA-ICP-MS) U-Pb carbonate geochronol- 
ogy: strategies, progress, and limitations, Geochronology, 2, 3361, https://doi.org/10.5194/gchron-2-33-2020, 2020.

Sagi, D. A., De Paola, N., McCaffrey, K. J. W., and Holdsworth, R. E.: Fault and fracture patterns in low porosity chalk and their potential influence on sub-surface fluid flow - A case study from Flamborough Head, UK, Tectonophysics, 690, 35-51, 2016.

Smeraglia, L., Aldega, L., Billi, A., Carminati, E., Di Fiore, F., Gerdes, A., Albert, R., Rossetti, F., and Vignaroli, G.: Development of an Intrawedge Tectonic Mélange by Out-of-Sequence Thrusting, Buttressing, and Intraformational Rheological Contrast, Mt. Massico Ridge, Apennines, Italy, Tectonics, 38, 12231249, 2019.

Starmer, I. C.: Deformation of the Upper Cretaceous Chalk at Selwicks Bay, Flamborough Head, Yorkshire: its significance in the structural evolution of north-east England and the North Sea Basin, P. York. Geol. Soc., 50, 213-228, 1995.

Starmer, I. C.: The concentration of folding and faulting in the Chalk at Staple Newk (Scale Nab), near Flamborough, East Yorkshire, P. York. Geol. Soc., 57, 95-106, 2008.

Starmer, I. C.: Folding and faulting in the chalk at dykes end, Bridlington Bay, East Yorkshire, resulting from reactivations of the flamborough head fault zone, P. York. Geol. Soc., 59, 195201, 2013.

Tillberg, M., Drake, H., Zack, T., Kooijman, E., Whitehouse, M. J., and Åström, M. E.: In situ Rb-Sr dating of slickenfibres in deep crystalline basement faults, Sci. Rep.-UK, 10, 1-13, 2020.

van Gent, H. W., Holland, M., Urai, J. L., and Loosveld, R.: Evolution of fault zones in carbonates with mechanical stratigraphy - insights from scale models using layered cohesive powder, J. Struct. Geol., 32, 1375-1391, 2010.

Viola, G., Scheiber, T., Fredin, O., Zwingmann, H., Margreth, A., and Knies, J.: Deconvoluting complex structural histories archived in brittle fault zones, Nat. Commun., 7, 13448, https://doi.org/10.1038/ncomms13448, 2016. von Hagke, C., Kettermann, M., Bitsch, N., Bücken, D., Weismüller, C., and Urai, J. L.: The effect of obliquity of slip in normal faults on distribution of open fractures, Front. Earth Sci., 7, 18, https://doi.org/10.3389/feart.2019.00018, 2019.

Walker, R. J., Holdsworth, R. E., Imber, J., and Ellis, D.: The development of cavities and clastic infills along fault-related fractures in Tertiary basalts on the NE Atlantic margin, J. Struct. Geol., 33, 92-106, 2011.

Whitham, F.: The stratigraphy of the Upper Cretaceous Flamborough Chalk Formation north of the Humber, north-east England, P. York. Geol. Soc., 49, 235-258, 1993.

Woodcock, N. H. and Mort, K.: Classification of fault breccias and related fault rocks, Geol. Mag., 145, 435-440, 2008.

Woodcock, N. H., Omma, J. E., and Dickson, J. A. D.: Chaotic breccia along the Dent Fault, NW England: implosion or collapse of a fault void?, J. Geol. Soc., 163, 431-446, 2006.

Woodcock, N. H., Miller, A. V. M., and Woodhouse, C. D.: Chaotic breccia zones on the Pembroke Peninsula, south Wales: Evidence for collapse into voids along dilational faults, J. Struct. Geol., 69 , 91-107, 2014.

Wright, V., Woodcock, N. H., and Dickson, J. A. D.: Fissure fills along faults: Variscan examples from Gower, South Wales, Geol. Mag., 146, 890-902, 2009.

Ziegler, P. A.: Geodynamic model for Alpine intra-plate compressional deformation in Western and Central Europe, in: Inversion Tectonics, edited by: Cooper, M. A. and Williams, G. D., Geological Society, London, Special Publications, 44, 63-85, 1989. 